\title{
Teacher Professionalism in Zambia: Reality or Pipe- Dream?
}

\author{
Simuyaba Eunifridah \\ Department of Education Administration and Policy Studies, The University of Zambia
}

\begin{abstract}
This article highlights the strategies that the newly established Teaching Council has put in place in its quest to professionalise teaching in Zambia. Since Zambia attained her political independence in October, 1964, there has been a great desire to ensure that teachers acquire professional status which would translate into an occupational status symbol. Against this background, the Government of the Republic of Zambia in conjunction with other stakeholders in the education sector has made strides in the direction of professionalising the teaching occupation. In this regard, the enactment of the Teaching Profession Act no.5 of 2013 and the development of a Code of Ethics and Conduct to regulate teachers' practice and professional conduct in government and private schools are some of the major milestones in trying to regulate the teaching profession. Despite having made tremendous strides in this direction, many structural and operational challenges have since made it difficult to actualise this status. It is for this reason that the paper discusses some structural and operational challenges associated with teacher professionalism in Zambia which make teacher professionalism a pipe-dream. The paper concludes by highlighting some prospects in Teacher professionalism in the post 2015 era.
\end{abstract}

Key words: Teacher Professionalism, Strategies, Challenges, Prospects, Reality, Pipe Dream.

\section{INTRODUCTION.}

$\mathrm{T}$ he teaching profession in Zambia, like many other countries in the region, has been under constant pressure from stakeholders calling for a more effective and responsive education system to the many needs of the nation. This pressure has been in existence for a long time and has thus necessitated the development of an Act of Parliament in 2013 which was meant to improve the teaching profession in general and in particular enhance the quality of educational services. The development of the Act of Parliament followed the actual enactment of the Teaching Profession Act No. 5 of 2013 on $21^{\text {st }}$ March, 2013 by the Zambian Parliament. This Act, among other things, provides for the establishment of the Teaching Council of Zambia (TCZ). The Act is primarily intended to provide for the regulation of teachers, their practice and professional conduct. It also provides for the accreditation and regulation of Colleges of Education through approval of teacher training programmes. From the year 2013 onwards, critical activities leading to teacher registration, certification and accreditation of Colleges of Education have been spearheaded by the Teaching Council of Zambia. Among the major breakthroughs in this initiative has been the recent development of the Code of Ethics and Professional Conduct for teachers and the development of subsequent legal documents such as The Statutory Instrument No.2 of 2016 (The Teaching Profession-Registration and Accreditation Regulation, 2016). Underpinning the range of initiatives that ensued has been the desire to attain teacher professionalism and consequently to improve quality in the Zambian educational system.

\subsection{Understanding the Concept of Professionalism}

Musaazi (1988) views a profession as one that carries with it 'intellectual' knowledge and great personal responsibility. Musaazi further contends that a profession is learned and is based on knowledge and not mere routine work. In addition, a profession is conceived as practical rather than simply academic or theory-based. Kim (2015) explains that in teacher education programs, a professional demonstrates behaviours which portray the knowledge and skills of the profession. Pratte and Rury (1991:60) defined professionalism as "an ideal to which individuals and occupational groups aspire, in order to distinguish themselves from other workers". Grady, Helbling and Lubeck (2008) added that a professional "exercises discretion in making decisions within the scope of their expertise, and they assume some authority for their own professional development" (p.603). On the other hand, Brehm, et.al. (2006) highlighted that professionals are expected to have specific knowledge which they utilise to make sound judgements, specialised training, characteristics that are unique to their field, and standards to which they are accountable. This implies that professionalism is multifaceted and therefore difficult to define.

Regardless of lack of a universally-accepted definition of professionalism, these definitions reveal that techniques or skills associated with professionalism are taught and it is this fact upon which professional education is predicated. A profession is strongly organised internally and is motivated by altruism (Musaazi (1988). As such professionals see themselves as working for the good of society. Thus, a professional person is one who knows the 'why' and the 'how'. He or she is someone with specialised knowledge and skill in a specific occupation which he or she regards as a lifelong vocation because of the nature of his/her special training and the satisfaction derived from doing the job. In the next section, some salient characteristics of a profession are provided before a link with education is provided. 


\subsection{The Relationship between a Profession and Teaching}

There are many characteristics of a profession which are highly associated with the teaching occupation. Firstly, and as implied above, a profession is based on a body of specialised knowledge and skill which one applies to the specific needs, tasks and problems met in the performance of daily work (Grady, Helbling and Lubeck,2008). In the education system, teachers require a high degree of intellectual ability and skill which are in turn prerequisites of a profession. For instance, if one is a teacher of Civic Education, neither his knowledge of Civic Education, nor his methods and skills of teaching are to be questioned due to his training and skills.

In addition, a profession demands competence in its members. Therefore, the degree of competence found in a profession is determined by the qualifications, training and experience required and the special provisions for in-service development. For example, teachers in Zambian secondary schools are for the most part university graduates. However, some of them may be diploma holders and their classifications are mainly determined by the type and length of training prescribed by the government. For instance, a senior secondary school teacher who holds a degree qualification in Zambia must have gone through four years of university education, while those who qualify to teach at junior secondary school level must possess at least two-year teacher's diploma (Manchishi, 2015). In as much as there may be variations in the qualifications required in order for one to perform at every level of the education system, the underlying factor is that the employees are expected to possess a certain level of competence.

Professional organisations to which teachers belong may also play an important role in enhancing their competence. These organisations may support professional development through in-service teacher training programmes, seminars, workshops, conferences and also through school monitoring by standards officers. In the Zambian context, education standard officers conduct school visits for practical information and on-the-spot observations and hold discussions with teachers. Therefore, the school monitoring or field visits by respective education officers, may be seen as a way through which teacher competence is enhanced. Moreover, the Teaching Council of Zambia (2015:5) states that the Teaching profession entails "a job that requires specialised training in teaching and instruction".

Moreover, a profession serves the needs of its members. For instance, a professional teacher is expected to have a satisfying job, an adequate salary, retirement benefits, the opportunity for professional advancement, and a reasonable social status among his colleagues and in the community he or she serves. Furthermore, a profession influences public policy in its field. Ideally, teachers as professionals in their various trade unions are expected to be in a position to influence government policies on education, particularly as it relates to curriculum reviews, organisational structure of the school system and professional training.
From the aforementioned, it is evident that a professional does not only benefit him/herself but also contributes to institutional improvement as well as society's well-being. A profession also provides its members an opportunity for group solidarity that arises partly through members' affiliation to professional associations or organisations. For example, in Zambia, there is the Zambian National Union of Teachers (ZNUT), the Secondary School Teacher's Union (SESTUZ), The Professional Teacher's Union of Zambia (PROSUZ) and The Basic Education Teachers' Union of Zambia (BETUZ). These teacher unions offer an avenue through which the profession of teaching provides general solidarity, respectability, prestige and security to its members (ZNUT, 2007). Although the main mandate for the trade unions is to represent members' interests to their respective employers, these professional bodies also have the duty of educating their members and the general public on important issues affecting them. They also keep people aware of new developments and new ideas in the profession and thus professional literature is produced periodically in order to meet this obligation (ZNUT, 2007). In producing professional literature, each of these trade unions has a research department which carries out research and disseminates findings at national and international fora.

Finally, a profession has ethical standards or a code of moral behaviour for every member to abide by. For instance, a profession carries a responsibility for a member to act in a manner required of a professional person. The behaviour of each member is a concern for all. In the case of schools, for example, the conduct of any teacher influences the attitudes of the students and the public toward the profession and education in general. The code of conduct is always designed to inspire a quality of behaviour that reflects the honour and dignity of the profession. It is not intended as an inflexible set of rules, but serves to measure the propriety or a member's behaviour in his working relationships. The Code of Ethics for the Teaching Profession in Zambia clearly spells out broad principles of basic values and behavioural standards that call for high levels of conduct by teachers (TCZ, 2016: iii).

\subsection{The Status of the Teaching Profession in Zambia}

The above discussion provides a general overview of what constitutes teacher professionalism. However, the list is not exhaustive. From the description of the concept of a profession in general, it would be safe to state that teaching is a profession, and precisely so because it shares the salient characteristics of a profession described above. Nonetheless, the question that begs to be answered is whether teaching is indeed a profession in Zambia, given a number of challenges that teachers face. From the outset, it has to be pointed out that it is not easy to provide a straightforward answer to this question because by the definition provided above, many of the attributes of a profession seem to be lacking in the teaching occupation in Zambia. For example, there are a number of teachers in some Zambian public, private and community schools without any requisite teaching qualifications or licence to practise (Simuyaba and Manchishi, 2016). 
It is commonplace to find some teachers in Zambia who are semi-illiterate people and are not much better than those they teach (Simuyaba, Falconer-Stout, and Kalimaposo, 2014; Simuyaba, Falconer-Stout and Mayapi, 2015). This is particularly the case in a number of community schools. In most cases, community school teachers have little education and have no professional backing or training to enable them teach efficiently (Simuyaba, Falconer-Stout, and Kalimaposo, 2014:62). This is counter to the qualities of a good teacher. A good teacher is expected to have professional knowledge and skills and these can only be acquired through training in various professional and academic subjects (Kim, 2015).

With the teacher registration exercise that was launched on the $3^{\text {rd }}$ of February, 2016, by the Hon. J. T. Phiri, the Minister of General Education in Zambia, the general belief that 'anyone can teach anything' shall come to pass. The Teaching Council of Zambia has now embarked on a nationwide sensitization programme advising the nation that only qualified teachers will be allowed to practise in Zambian schools. This message is in accordance with the provisions of the Teaching Profession Act No. 5 of 2013, which defines a teacher as follows:

[a] person who is qualified, registered and teaches or instructs, a head of a school, a principal or lecturer of a college of education, a technical education instructor, head of department of education or an education unit at any other educational institution other than a university.

Going by this legal document, an individual shall be considered to be a teacher if that individual has studied content courses in their areas of specialisation, foundations of education and methodology courses. Once one possesses such qualifications, then this teacher shall be considered qualified to teach learners at a given level(s) of the educational system and shall be registered with the Teaching Council of Zambia in accordance with the Teaching Profession Act No. 5 of 2013. Upon registration, the teacher is expected to apply for a Certificate of Practice which will be renewable every three (3) years.

After the implementation of this law in the post-2015 era (TCZ, 2016: 2-4), it is envisaged that anyone who does not fit into the above definition of a teacher shall not practice as a teacher in any Zambian school. This authority from the Teaching Council is clearly articulated in Section 26 of the Teaching Profession Act (Act No. 25 of 2013) which states that: A person shall not, unless the person is a teacher and holds a practising certificate under the Teaching Profession Act:

(a) Practise as, be employed as, offer teaching services as or hold out to be a teacher.

(b) Adopt, use or exhibit the titles "registered teacher" or any other title or abbreviation of like description, or

(c) Do anything likely to lead persons to infer that the person is a registered teacher.
Section 4 of the same Act further stipulates that "a person who commits an offence is liable, upon conviction, to a fine not exceeding three hundred thousand $(300,000)$ penalty units or to imprisonment for a period not exceeding three (3) years, or to both.

This therefore, means that the notion among some academics that: 'once someone has a university degree, then he/she can teach' will be dismissed in the post-2015 agenda. As educators, it is common knowledge that academic knowledge alone is not enough to make a good teacher (Musaazi, 1978, Kim, 2015) and therefore some formal preparation in a teacher training college is necessary. The special skills acquired in a college of education or University College of Education distinguish the professional teacher from a nonprofessional teacher. For this very reason, the Teaching Council of Zambia will ensure that all those without qualifications will not be issued with Certificate of Practice as teachers (i.e. Form X, Regulation 5, 2016) and consequently, will be prohibited by law to practise as teachers.

\subsection{Structural and Policy Implementation Challenges}

The process of changing the 'status' of teaching as a profession in Zambia is faced with a number of challenges which range from structural to actual policy implementation. For example, though plans are underway to implement the provisions of the Teaching Profession Act no. 5 of 2013, as well as the Teaching Profession Regulation of 2016, many unqualified persons still teach in Zambian schools in both public and private schools (Simuyaba, E.; Stout Falconer Z.J and Kalimaposo, K. (2014:62). Thus it is fair to argue for now that teaching is not yet a profession in Zambia, and thus going by what is obtaining now, it is safe to argue that teacher professionalism in Zambia is a pipe-dream.

In addition, the challenge to have teaching as a profession in Zambia has been compounded by some challenges obtaining in the teaching profession in Zambia which include among others: "increase in examination malpractices, teacher misconduct, poor pupil performance and work culture" (Teaching Council of Zambia, 2016:3). This development can partly be attributed to the absence of the professional teacher's regulatory body and a Code of Ethics prior to the enactment of the Teaching Profession Act No. 5 of 2013 and its implementation.

Furthermore, teaching in Zambia lacks the prestige of other professions such as medicine and law. In many advanced countries like Britain and the USA, no one is allowed to teach in a primary or secondary school, however learned they may be, unless they have completed a period of professional training (Musaazi, 1988). In these countries, there are minimum standards for entry into the teaching profession. Therefore, in such nations, teaching can be considered a profession. The situation is different from Zambia since postindependence education policies provided that anyone who had basic qualifications at secondary school level could attend in-service teacher training and be allowed to teach, have 
existed for a long time. During the early and late postindependence times, anyone who possessed basic education could attain teacher training and was allowed to teach or practise as a teacher. This practice is still prevalent in Zambia particularly, in rural/peri-urban areas and especially in community schools. With such policies and practices, teacher professionalism in Zambia is still a pipe-dream.

It is worth noting here that the presence of unqualified teachers in the system is attributed to the time when the provision of education among communities was legalised by the Ministry of Education in the early 1990s, following the liberalised education policies (Masaiti and Simuyaba, 2018). In Zambian community schools, anyone who had a grade 9 certificate was qualified to teach, including those who completed at the grade 12 school level but without sufficient O' Levels to enable them attend a teacher training college. The third category of unqualified teachers come from private Colleges of Education. Most private colleges have been enrolling student teachers who do not meet the prescribed minimum entry requirements, solely for purposes of gaining profits (Teaching Council of Zambia Inspection Report, 2016). This trend seems to have been on the rise especially in the face of competition for students and the need to make money, hence; the presence of both qualified and unqualified teachers in Zambia's educational system. However, we should thank the Teaching Profession Act No 5 of 2013 whose implementation would resolve this challenge and ensure that teacher professionalism becomes a reality in Zambia's educational system. The Act provides for the classification of members to be registered as teachers, and it goes as follows:

Pursuant to part III section 9 sub-section (1), (2) and (3) of the Teaching Profession Act No. 5 of 2013, the classification of members to the teaching profession shall include qualified teachers or education practitioners and other personnel who are associated with the Teaching Profession.

The above Act gives 'teeth' to the Teaching Council of Zambia to eliminate or drastically reduce chances of members who masquerade as teachers without the stipulated minimum requirements for teaching to practise as such. It is clear then that once this implementation takes root, the Zambian Ministry of General Education will be moving towards achieving teacher professionalism. Once this is done, teacher professionalism will become a reality in Zambia.

\subsection{Some ways for enhancing Teacher Professionalism in Post-2015 Era}

The previous sections have identified some policy gaps and structural challenges that render teacher professionalism a pipe-dream in Zambia. It is therefore prudent to support the measures taken by the Ministry of General Education and indeed other stakeholders to turn teaching into a respectable profession through the provision of professional training for all eligible teachers from pre-primary to university levels. This kind of training could be provided in the existing
Colleges of Education and in University faculties of education. This would also entail that members who do not possess the requisite qualifications and who might be teaching should not be offered practising certificates during the teacher certification phase later in 2016 by the Teaching Council of Zambia. Instead, they should enrol for in-service teacher training programmes to enable them to upgrade their qualifications (Masaiti and Simuyaba, 2018). Such activities will drive teacher professionalism into a reality.

In addition, other policy directives could be given, for example, the minimum entry requirement into teaching at primary level should be raised to at least three-year diploma level while at the community school level, several programmes of in-service training should be organised for community school teachers. At the end of such programmes, examinations and certificates of competence could be given. This would act as qualifications that could enable such people to teach in community schools. A further full-time professional training should be devised to enable community teachers acquire academic certificates which would enable them to register as teachers in the various categories prescribed by the Teaching Council of Zambia (TCZ, 2016).

Nevertheless, it should be pointed out that conducting such ambitious activities meant to improve quality in teaching and promoting professionalism, would entail serious financial investment on the part of government and other concerned stakeholders, given the high cost involved in training teachers at various educational levels. Alternatively, the cost could be borne by members who wish to upgrade their qualifications in order for them to remain relevant and effective to the educational system in Zambia. In spite of the educational cost that may go with the suggested reforms, there is need to take serious measures in implementing them as 'quality always goes with cost'. Realising the importance of this fact, it is possible for Zambia to be on course towards making teacher professionalism a reality in the post-2015 era.

With regard to poor attitude towards work, it is expected that each registered and certified teacher should be served with a copy of the Code of Ethics and Conduct for the Teaching Profession in Zambia. Armed with the contents of the document, all teachers would in turn be expected to have a changed attitude towards work due to clauses that stipulate varying forms of penalties that a member would receive if and when they breach the Code of Ethics and Conduct for the teaching profession. Furthermore, given the demands of the Code of Ethics and Conduct, a new orientation towards work would inevitably be created among teachers. This means that the Code of Ethics and Conduct would instil in teachers a healthy attitude to teaching and good discipline towards work.

It is common knowledge that poor remuneration for teachers across the globe is a thorny issue for many employers. However, if the tenets of professionalism are anything to go by, teachers should be well remunerated in order to boost their morale which is one of the key attributes for enhancing professionalism. Nonetheless, it has to be pointed out that 
improvements in teachers' salaries and conditions of service alone are not sufficient grounds for making better teachers who are intellectually and professionally equipped to carry out the important task of educating the Zambian youths. Furthermore, the payment of a renewal fee for a teacher's practicing licence at the end of every three-year period as obtaining in the provisions of the Teaching Profession Act No. 5 of 2013 is not sufficient ground to measure teacher competence over a period of time. In order to determine whether the teacher is still competent as might have been the case three years previously, TCZ national examinations of teacher competence and certification are recommended. It is assumed that if the teacher passed the proposed competencebased examination, teacher professionalism will be enhanced.

It is further worth noting that the educational system in Zambia has been expanding rapidly since independence in 1964.The main structural challenge facing the nation's educational system now and in the foreseeable future is how to match quantity with quality. In response to the above challenge, the educational system should be in a position to cope with the current needs of the country. Thus the graduates of the education system must be fully equipped with the values, knowledge and skills necessary for development. This means also that if teacher professionalism is to be realised, the Teaching Council of Zambia should ensure that those who teach in schools and colleges are thoroughly prepared for the tasks ahead of them in their teaching profession. To match quantity with quality, it is within the mandate of the Teaching Council of Zambia to accredit Colleges of Education (The Teaching Profession Act, 2013 and The Statutory Instrument No.2, 2016, Regulation 9) and to ensure that what is taught in these institutions of learning is within the confines of the revised National Curriculum Framework. Once both public and private colleges of education are monitored by this regulatory body, namely Zambian Qualifications Authority (ZAQA), there is a high likelihood that there would be improvement in the efficiency and delivery of the educational system thereby ensuring that the fruits of teacher professionalism are felt at levels of the Zambian society.

\subsection{Is Teacher Professionalism a Reality or Pipe-dream?}

As I conclude this paper, I wish to argue that teacher professionalism in Zambia is still a pipe-dream. I have further demonstrated that for teacher professionalism to be a reality, a lot more needs to be done. Thus it is highly envisaged that the newly-established Teaching Council of Zambia would facilitate the professionalisation of the Teaching Profession in Zambia. This would be facilitated by the actual implementation of the provisions of the Teaching Profession Act no. 5 of 2013 as well as the adoption and implementation of the Council's Code of Ethics and Conduct for the Teaching Profession (TCZ, 2016). The Code of Ethics, which was a missing link, is an important document as it stipulates the dos and don'ts for all members in the teaching profession. Any member's breach of the Code results in a penalty, depending on the gravity of the offence.
It is further expected that by the end of 2016, all Colleges of Education in Zambia would be accredited to the Council and that the more than 130,000 teachers from both public and private sectors would register as teachers with the Teaching Council of Zambia. By so doing, the Teaching Council hopes to place professionals at an appropriate level which will further bring about job satisfaction to teachers and the resultant quality service delivery and general quality of education. Once this process is done, it is hoped that teacher professionalism will be realized in Zambia. Going by what has been said, the dream of realizing teacher professionalism in Zambia partly lies in the actual implementation of the policies and regulations of the Teaching Council of Zambia.

Finally, I wish to recognize the fact that The Teaching Council of Zambia as an institution mandated to drive teaching into a profession, cannot succeed as a single entity in realizing this mammoth task. I therefore call for concerted efforts of all educational stakeholders, including teacher training institutions, in turning teaching into a profession. Other than training institutions, the stakeholders that I recognize in helping to turn teaching into a profession are the politicians, the Ministry of Education officials, the Leaders of the Teacher Unions, the School Managers, as well as the teachers themselves. I therefore implore a change of attitude among teachers themselves, if teacher professionalism is to be a reality in Zambia.

\section{ACKNOWLEGEMENT}

I am greatly indebted to the Teaching Council of Zambia for sponsoring the production of this manuscript which was presented at the African Forum for Teaching and Learning Conference held in Avani Hotel, Livingstone, Zambia. The paper was later published in a print media by Aftra in 2017.

\section{REFERENCES}

[1] Brehm, B. Breen, P., Brown, B., Long, L., Smith, R., wall, A. and Wallen, N.S (2006). "Instructional Design and Assessment: An Interdisciplinary Approach to Introducing Professionalism'. American Journal of Pharmaceutical Education. Vol.70 (4), 1-5.

[2] Brown, D. and Ferril, M.J. (2009). "The Taxonomy of Professionalism: Reframing the Academic Pursuit of Professional Development". American Journal of Pharmaceutical Education. Vol.83 (4)1-10.

[3] Grady, M.P., Helbling, K.C. and Lubeck, D.R. (2008) Teacher Professionalism since a Nation at Risk. Phi Delta Kappan, Vol 89, 603-604, 607.

[4] Kelly, M.J. (1996). The Origins and Development of Education in Zambia. Lusaka: Image publishers.

[5] Kim, L.C. (2015). "Defining Professionalism in Teacher Education Programmes". Vol. 2(2)23-25.

[6] Manchishi, P.C. and Masaiti, G (2011) "The University of Zambia Pre- Service Teacher Education Programme: Is it Responsive to Schools and Community's Aspirations?" European Journal of Education Studies. Vol 3, No. 2.

[7] Manchishi, P.C. (2015). Reforming Zambian Pre-service Teacher Education for Quality Learning. Lusaka: University of Zambia Press.

[8] MoE (1996). The National Policy on Education, Educating our Future. Lusaka: MoE.

[9] Musaazi, J.C.S (1988). The Theory and Practice of Educational Administration. London: Macmillan. 
[10] Pratte, R. and Rury, J.L. (1991) "Teachers, Professionalism and the Craft". Teachers' College Record, 93 (1) 59-72. http//www.tcrrecord.org ID No.255. Date Accessed 5.6.2015.

[11] Simuyaba, E. Falconer-Stout, Z. J. and Mayapi, T. (2015) "Government Teachers in Community Schools: Two Zambian Success Stories". Time to Learn Case Study Series. Lusaka: USAID.

[12] Simuyaba, E. and Chibwe Portipher (2016) Teacher Professionalism in Zambia: Practices, Challenges and Prospects in the Post 2015 Era. Proceedings of the $67^{\text {th }}$ IIER International conference, Sweden, Stockholm, 02 April, 2016. ISBN 978-9385973-89-5. Available http://dspace.unza.zm/handle/123456789/6960.

[13] Simuyaba, E.; Stout Falconer Z.J and Kalimaposo, K. (2014) "The Role of Active Parent Community School Committees in Achieving Strong Relative School Performance in Zambian Community Schools". Southern Africa Review of Education. Vol. 20, 2. 59-79.

[14] Simuyaba, E.; Banda, D, Mweemba, L. and Muleya, G (2015). "Theory against Practice: Training of Teachers in a Vacuum". Journal of Education and Social Policy. Vol. 2, No. 5. 2015. Also available on http://www.encompassworld.com/resources/roleactive-parent-community-school-committee. Accessed on $2^{\text {nd }}$ March, 2016.

[15] Masaiti G. and Simuyaba E. (2018). 'University Education in Zambia in the Face of Austerity: History, Trends and Financing' in Education in Zambia at Fifty years of Independence and beyond. Lusaka: Unza press. Also available on https://www.researchgate.net/publication/

[16] Simuyaba, E and Manchishi, P.C. (2016). "Teacher Education in Zambia: History, Current Status and Future Prospects".in Vol 3 of The International Handbook on Teacher Education Worldwide' available

https://www.journals.uchicago.edu/doi/abs/10.1086/662001?.jo urnalCode=cer

[17] The Teaching Council of Zambia. (2016). Code of Ethics for the Teaching Profession in Zambia. Lusaka: TCZ (UP. 2016 Version).

[18] GRZ. (2013). The Teaching Profession Act No. 5 of 2013. Lusaka: Government Printers.

[19] ZNUT (2007). The Zambia National Union of Teachers Report (2007). Lusaka. ZNUT. 